\title{
Grammar intervention in children with specific language impairment: an integrative literature review
} \author{
Carmen Julia Coloma Tirapegui ${ }^{1,2}$ \\ Daniela Paz Rojas Contreras ${ }^{1}$ \\ https://orcid.org/0000-0002-3954-8327 \\ Zulema del Carmen de Barbieri Ortiz' \\ https://orcid.org/0000-0001-6449-7712
}

Universidad de Chile, Departamento de Fonoaudiología, Santiago, Chile.

2 Universidad de Chile, Centro de Investigación Avanzada en Educación, Santiago, Chile.

Research support Source: Regular FONDECYT nº1170705 from Comisión Nacional de Investigación y Tecnología (CONICYT); Basal Fund for Centers of Excellence, project FBO003 from PIA-CONICYT

Conflict of interests: Nonexistent

\section{(c) (i)}

Received on: May 30, 2019 Accepted on: October 7, 2019

Corresponding address: Carmen Julia Coloma Tirapegui Avenida Independencia 1027, Independencia

Casilla: 8380453 - Santiago, Chile

E-mail: ccoloma@med.uchile.cl

\section{ABSTRACT}

Aim: to review the literature reporting grammar-based interventions designed to improve morphosyntactic skills among children with specific language impairment (SLI).

Methods: several studies reporting grammar-based interventions were analyzed. The criteria for selecting the articles were determined as follows: a) publication date within the last ten years; b) studies that reported a grammar-based intervention; c) groups of study constituted by children with SLI, aged 3.0 to 12.0 years; d) design including Pre and Post measures; e) articles reporting quantitative/qualitative data analyses. The databases selected for this review were: Lilacs, PubMed, Embase, Scopus, ISI-Web of Science, and EBSCOhost.

Results: most studies reported interventions focused on expressive grammar, providing no particular details about the specific grammar contents considered. Interventions usually consisted of implicit approaches implemented as individual therapy. Studies reported children with SLI as generally improving on intervened skills.

Conclusion: all of the grammar-based intervention programs described in the selected studies, seemed to be equally adequate when working with children with SLI.

Keywords: Child Language; Language Disorders; Language Therapy; Speech, Language and Hearing Sciences 


\section{INTRODUCTION}

Specific Language Impairment (SLI) is generally defined as a disorder of the linguistic development, which occurs in the absence of evident neurological damage, hearing deficit, severe environmental deprivation or mental retardation ${ }^{1}$. It has been estimated that this disorder affects approximately $7 \%$ of children ${ }^{2,3}$ and that it persists until adolescence ${ }^{4,5}$.

One of the most outstanding linguistic characteristics in children with $\mathrm{SLI}$ is their grammatical problems ${ }^{6}$. These are generally considered one of the nuclear symptoms of this disorder ${ }^{7}$. In addition, there are children with SLI who are characterized by only demonstrating difficulties in grammatical aspects ${ }^{8}$.

Grammar difficulties occur both at an expressive and comprehensive level. In this regard, it has been observed that expressive morphosyntactic disturbances are more evident in young children (up to 8 years) and that receptive errors are expressed even in adolescence ${ }^{9}$. Although grammatical errors are a transversal symptom, difficulties may manifest differently in speakers of different languages ${ }^{1,10}$. For example, English-speaking children show mainly a compromise in the morphology of verbs, in particular related to the use of third person singular and to the morphemes of the past tense of regular verbs ${ }^{11}$. On the other hand, Spanish speakers, in addition to their difficulties with verbs, exhibit difficulties with the use of articles, clitic pronouns and prepositions ${ }^{12-14}$.

The Procedural Deficit Hypothesis is one of the explanations proposed to understand the grammatical difficulties of children with SLI. This hypothesis states that grammar involves the learning of rules, which requires the use of procedural memory. Instead, lexical knowledge depends on declarative memory. In children with SLI, procedural memory would be compromised and therefore grammatical areas would be affected. In contrast, declarative memory would be unscathed ${ }^{1}$.

The relevance of grammatical difficulties in children with SLI requires developing interventions that contribute to overcome or compensate this problem.

Kamhi ${ }^{15}$ states that in therapy, there can be a differentiation between the approaches (referring to the how) and the contents (referring to the what) that should be used. Regarding the approaches, Ebbels ${ }^{16}$ distinguishes two types: implicit and explicit. Implicit approaches address the teaching of grammatical aspects through procedures such as reformulation, imitation, expansion or modeling. This perspective seeks that children are able to infer morphosyntactic rules without being explicitly instructed. From this approach, it has been found that the use of reformulation is appropriate for children with SLI when programs with specific grammatical objectives are applied ${ }^{17}$.

In turn, explicit approaches directly teach the rules of grammar, through procedures that involve metalinguistic reflection, which is generally based on visual clues $^{16}$. It is argued that visual clues are useful to support the teaching of grammar, because children with SLI have strong visual skills ${ }^{18}$.

According to Kamhi ${ }^{15}$, the approaches just described correspond to the same intervention model that varies in intensity and specificity. Thus, at one end of the therapy specter would be the explicit approach in which specific grammatical structures are explicitly taught through metalinguistic reflection. At the other extreme would be the implicit approach where, through procedures such as modeling or reformulation, these structures are learned, without direct instruction.

Regarding which approach is best for children with SLI, it seems that the explicit ones would be more appropriate. This is because these children show difficulties with implicit grammatical learning, due to their issues in procedural memory ${ }^{1,16}$. On the other hand, declarative memory, based on explicit learning, would not be affected ${ }^{1,16}$.

Also, it has been proposed that at different stages and ages children respond differently to each of these approaches. Thus, implicit approaches would be more suitable for young children ${ }^{16}$, while explicit ones are more appropriate for older children ${ }^{18}$. The previous statement is consistent with a study in which speech therapists reported that the most used procedures vary according to the school period in which the child is. Thus, in pre-school stage, modeling is the most used procedure, followed by reformulation and imitation (implicit approach). In the school stage, modeling is practically not used and the most common procedure is explicit teaching (explicit approach) ${ }^{19}$.

Finally, it is important to point out that implicit approaches fundamentally help children with morphosyntactic expression difficulties ${ }^{15}$. On the other hand, explicit approaches support mainly schoolchildren with receptive grammatical difficulties ${ }^{16}$.

As previously stated, in addition to the approaches that are used in an intervention, there are grammatical contents that must be addressed ${ }^{15}$. The establishment of these contents should consider the language spoken by the child, since grammatical difficulties manifest 
differently in each language ${ }^{1,10}$. In English, the contents most commonly addressed in the pre-school stage, according to language therapists, are plural form and verbs in present progressive. In the school period the contents most usually applied are regular and irregular verbs in the past tense, pronouns and plurals ${ }^{19}$.

Another topic that has been discussed regarding grammatical intervention in children with SLI is the duration that the session should have for the treatment to be beneficial. Recent work shows that there are no differences between sessions that last fifteen minutes and the ones that last thirty minutes. Consequently, it is suggested to prefer a shorter session ${ }^{20}$.

Despite the importance of treating grammatical difficulties in children with SLI, it is noteworthy that there are significant gaps in the literature on the effectiveness and efficiency of the intervention, both in children with receptive grammatical problems and those with expressive grammatical difficulties ${ }^{16}$.

Thus, the question of how the intervention used to support grammatical development in children with SLI is, turns out to be relevant and valid. Therefore, the objective of this paper is to review the literature that addresses grammar intervention aimed at increasing morphosyntactic abilities in children with SLI.

\section{METHODS}

\section{Literature search procedures}

An integrative review of the literature was carried out between August and October of 2018. For this review, two procedures were used.

The first one consisted in researching the following databases: Lilacs, PubMed, Embase, Scopus, ISI-Web of Science and EBSCOhost. These were chosen because they address issues related to therapeutic intervention, grammar and SLI. Thus, some focus primarily on biological and medical sciences and others address content both related to philosophy and humanities. The cross-reference between databases that address medical and biological contents and the ones that address philosophy and humanities allowed to find the articles analyzed in this review.

The terms used for the search were traced in English and Spanish. English was chosen because it is the language in which most scientific works are disseminated. As a matter of fact, abstracts of articles published in any language count with an English translation. In addition to the aforementioned, it is known that evidence on grammar in children with SLI has been obtained mainly from studies conducted with English speakers ${ }^{21}$. On the other hand, Spanish was privileged as it is the most spoken Romance language in the world ${ }^{22}$. Along with the above, most journals that address the issue of language difficulties in Latin America and Spain disseminate their articles in Spanish. finally, Brazilian magazines disseminate articles in Portuguese and English and some of them accept works in Spanish.

The terms used in English were: "classroom and grammar and intervention", "grammar and intervention", "intervention and grammar and SLI", "classroom and children and SLI and grammar", "grammatical and treatment and SLI". In turn, the words used in Spanish were: "sala de clase y gramática e intervención" "gramática e intervención", "intervención y gramática y TEL", "sala de clase y niños y TEL y gramática" and "gramática y tratamiento y TEL". The terms "intervention / intervención" and "treatment / tratamiento" were used because they involve the idea of therapy, support plans, programs and training. On the other hand, the words "grammar / gramática" and "grammatical / gramatical" were used since they include the concepts of morphology and syntax. The descriptor "classroom / sala de clases" was included, because when using only the descriptors "grammar / gramática", "intervention / intervención" and "SLI / TEL" very few articles were found. Thus, when considering it within the search, more studies emerged.

All descriptors were examined without limiting the search, with the exception of Scopus database, in which the search for all terms was limited to the option of "title, abstract and keywords", because when considering all fields, many articles appeared which did not relate to the topic.

For the rest of the databases, there was only restriction of the terms "Grammar and intervention". In the case of PubMed and Embase, the search was limited to the title and the abstract simultaneously. In ISI, Lilacs and Ebscohost, which did not present the simultaneity option, the exploration was restricted to the title. This is because when these terms were not limited, the number of articles without relation to the topic increased considerably.

The second procedure consisted in searching for articles from the ones already selected in the mentioned databases. Specifically, the references found in those articles were placed in the Google Scholar search engine. All those that appeared in the Related Articles 
section were reviewed and those that met the inclusion criteria were selected.

\section{Inclusion Criteria for articles}

1. Articles must contain original data.

2. Articles should report on applications of grammar intervention programs exclusively for children with language difficulties.

3. Articles should have been published in the last 10 years, that is, between 2008 and 2018.

4. The research design should include: a) study group, b) evaluation pre and post program implementation and c) quantitative or qualitative analysis of the data.
5. The intervention must be carried out in preschoolers and / or in schoolchildren with SLI.

6. The age range of children with SLI should fluctuate between 3.0 years and 12.0 years.

\section{Accepted articles and rejected articles}

The databases showed 1,171 articles and 4 articles were found through the Google Scholar search engine, and 1,057 articles were excluded due to their titles, 73 for being duplicated, 15 after the revision of the abstract and 7 after reading the complete text. Finally, there were 23 articles left which met the inclusion criteria, consequently they were analyzed in their full version.

Image 1 summarizes the search process performed for the selection of articles.

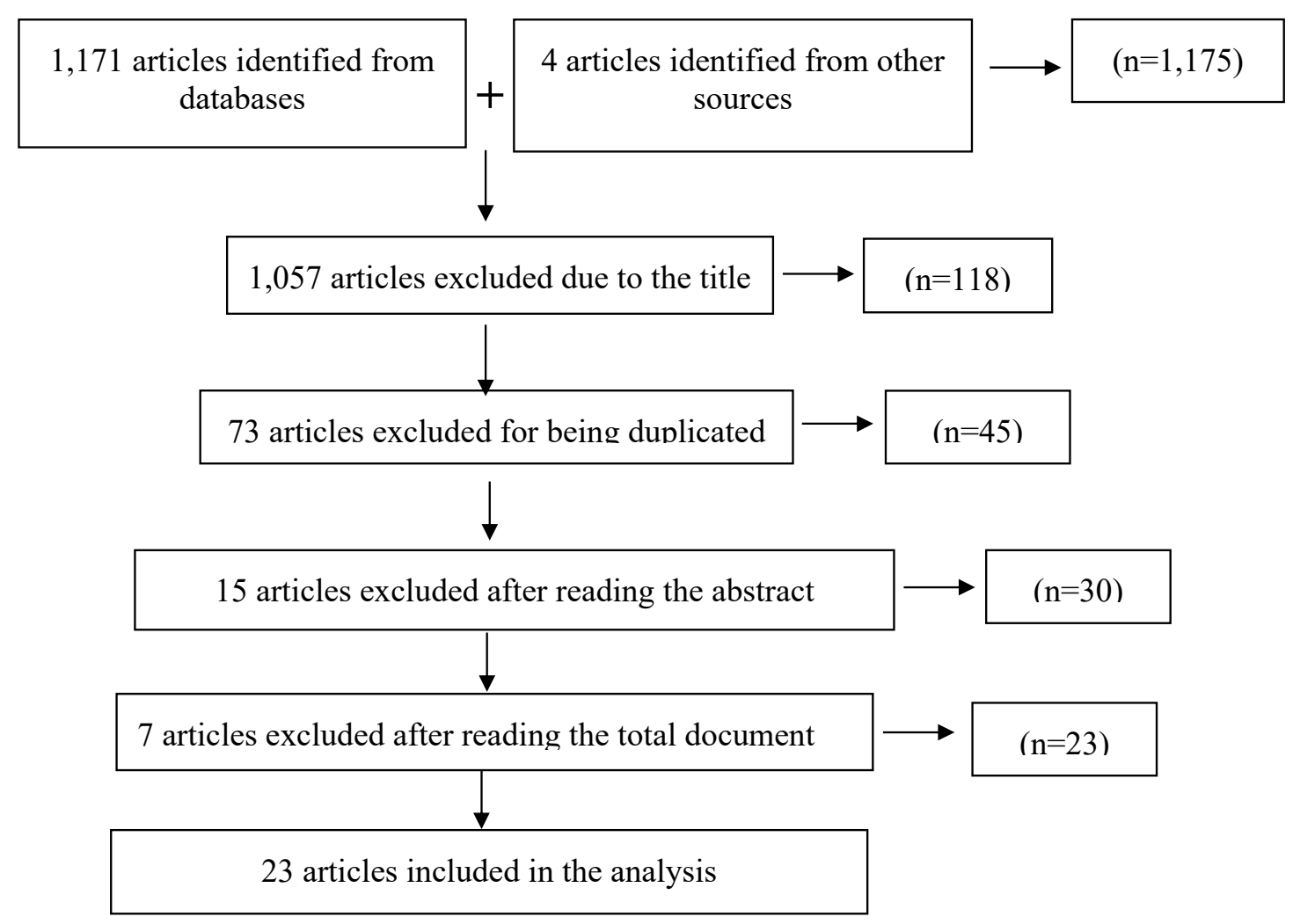

Figure 1. Flowchart for article selection

It should be noted that when the descriptors were tracked in Spanish, no results were obtained in any database. The only exception was EBSCOhost which when using the terms "sala de clases y niños y TEL y gramática" showed 10 articles. None were considered into the analysis, because they did not meet the inclusion criteria. Due to the aforementioned, the tables presented contain information on the articles that correspond to the search performed with the terms in English.

Table 1 shows the total number of articles found (number on the left) and the total number of articles selected (number on the right). Table 2 shows the distribution of the selected articles by their source. The numbers correspond to the ones under which they are found in the references section. 
Table 1. Quantity and distribution of the articles found and selected, according to descriptor and database used

\begin{tabular}{lcccccc}
\hline & Lilacs & PubMed & Embase & Scopus & $\begin{array}{c}\text { ISI Web of } \\
\text { Science }\end{array}$ & EBSCOhost \\
\hline Classroom and grammar and intervention & $0 / 0$ & $16 / 4$ & $13 / 2$ & $49 / / 3$ & $61 / 0$ & $93 / 2$ \\
Grammar and intervention & $0 / 0$ & $110 / 4$ & $134 / 5$ & $390 / 11$ & $15 / 3$ & $18 / 4$ \\
Intervention and grammar and SLI & $0 / 0$ & $26 / 6$ & $11 / 3$ & $23 / 6$ & $39 / 12$ & $35 / 5$ \\
Classroom and children and SLI and grammar & $0 / 0$ & $77 / 2$ & $2 / / 2$ & $0 / 0$ & $3 / 3$ & $2 / 2$ \\
Grammatical and treatment and SLI & $0 / 0$ & $31 / 7$ & 0 & $23 / 6$ & $0 / 0$ & 0 \\
\hline
\end{tabular}

Legend: SLI (specific language impairment)

Table 2. Distribution of the selected articles, according to descriptor and source

\begin{tabular}{|c|c|c|c|c|c|c|}
\hline & Lilacs & Pubmed & Embase & Scopus & $\begin{array}{l}\text { ISI Web of } \\
\text { Science }\end{array}$ & EBSCOhost \\
\hline Classroom and grammar and intervention & 0 & $\begin{array}{c}25,32,36 \\
37\end{array}$ & 25,36 & $25,35,36$ & 0 & 25,36 \\
\hline Grammar and intervention & 0 & $\begin{array}{c}25,32,36 \\
39\end{array}$ & $\begin{array}{c}24,25,32 \\
3639\end{array}$ & $\begin{array}{c}25,26,27 \\
30,32,34 \\
35,36,39 \\
42,45\end{array}$ & $32,36,42$ & $\begin{array}{c}32,36,33 \\
42\end{array}$ \\
\hline Intervention and grammar and SLI & 0 & $\begin{array}{l}25,27,28 \\
32,37,39\end{array}$ & $25,36,39$ & $\begin{array}{l}25,26,27 \\
32,34,39\end{array}$ & $\begin{array}{l}25,27,30 \\
32,34,36 \\
37,39,41 \\
42,43,45\end{array}$ & $\begin{array}{c}25,31,32 \\
34,40\end{array}$ \\
\hline Classroom and children and SLI and grammar & 0 & 25,37 & 25,37 & 0 & $25,36,37$ & 25,37 \\
\hline Grammatical and treatment and SLI & 0 & $\begin{array}{c}25,27,28 \\
31,32,40 \\
41\end{array}$ & 0 & $\begin{array}{l}25,27,28 \\
31,40,41\end{array}$ & 0 & 0 \\
\hline Other sources: & \multicolumn{6}{|c|}{$23,29,38,44$} \\
\hline
\end{tabular}

Legend: SLI (specific language impairment)

\section{REVIEW OF LITERATURE}

Tables 3 and 4 can be found below, which summarize the most important information from the selected articles. The complete bibliographic information of the articles analyzed is in the references section and they are marked with an asterisk.

Table 3 shows the objectives / hypotheses, the participants to whom the grammatical intervention was applied and the language spoken by the children. 
Table 3. Objectives/hypotheses, participants and language

\begin{tabular}{|c|c|c|c|c|}
\hline Article & \multirow{2}{*}{ Objective /hypothesis } & \multicolumn{3}{|c|}{ Participants } \\
\hline Author/Year & & Language & Experimental Group & Control Group \\
\hline $\begin{array}{l}\text { Leonard L.B., et } \\
\text { al. } 2008^{23}\end{array}$ & $\begin{array}{l}\text { To study three different interventions and observe the ef- } \\
\text { fects immediately after therapy and one month after the } \\
\text { treatment is finished. }\end{array}$ & English & $\begin{array}{l}\text { Experimental Group 1: } \\
\text { The treatment focused on working } 3^{\text {rd }} \text { person } \\
\text { of the singular }\end{array}$ & \\
\hline
\end{tabular}

Experimental Group 2:

Treatment focused on working with verb to be: is, are, was.

Experimental group 3:

Children received general language stimulation.

In total, there were 33 children with SLI, aged between 3.0 and 4.8 years old. Each group completed one of the treatments.

The analysis was performed on 8 children of each group.

Leonard, L.B. et To study the changes through time in the use of morpholal. $2017^{24}$ ogy of time and verbal consistency, in precision, diversity or productivity in children with SLI.

Motsch $\mathrm{H}$, et al. To investigate whether children with SLI, trained in $2008^{25}$ Context-Optimizationprogram during classes, achieved significative improvement in case marking. To investigate whether this therapeutic approach was more effective than traditional methods used on a control group.

Camarata S, et To examine if grammatical intervention focused on exal. $2009^{26}$ pressive grammar is associated with an improvement in receptive language.

Yoder P, et al. To know which grammatical intervention (1. milieu lan$2011^{27}$ guage teaching -MLT- and 2. broad target recasts -BTR) enables more the generalization and maintenance in time of grammatical aspects intervened in preschoolers with SLI.
English 17 preschoolers with SLI. Range of age: 36 51 months old. Average: 42 months old.

German 63 children with SLI between 8.6 y 10.1 Control group: 63 children years old. They received Context-Optimiza- with SLIbetween8.6 y 10.1 tion therapy for case marking (Accusative years old. They received and Dative). a different therapy in case marking (accusative and Dative).

English 21 children with SLI with receptive difficul6 children with SLI, ties. Average age of 31 months. with receptive language difficulties.

\section{English Experimental group 1: \\ 30 preschoolers with SLI who received BTR} therapy.

Experimental group 2:

27 preschoolers with SLI who received MLT therapy.

In both groups the children must be between 30 and 60 months old.

\begin{tabular}{|c|c|c|c|c|}
\hline $\begin{array}{l}\text { Yoder P, et al. } \\
2013 .{ }^{28}\end{array}$ & $\begin{array}{l}\text { To know how speech processing speed is related to } \\
\text { grammatical intervention in children with SLI. }\end{array}$ & English & $\begin{array}{l}47 \text { preschool children with SLI, with average } \\
\text { age of } 3.5 \text { years old. }\end{array}$ & $\begin{array}{l}47 \text { children with typical } \\
\text { development of language, } \\
\text { average age } 3.5 \text { years old. }\end{array}$ \\
\hline $\begin{array}{l}\text { Gallego JL. } \\
2012^{29}\end{array}$ & $\begin{array}{l}\text { To know if a grammatical stimulation program can modify } \\
\text { the competence of students at a morphosyntactic level. }\end{array}$ & Spanish & $\begin{array}{l}16 \text { children aged } 5 \text { years old with language } \\
\text { impairment. }\end{array}$ & $\begin{array}{c}16 \text { children aged } 5 \\
\text { years old with language } \\
\text { impairment. }\end{array}$ \\
\hline $\begin{array}{l}\text { Kulkarni A, et al. } \\
2013^{30}\end{array}$ & $\begin{array}{l}\text { To assess the effectivity of Shape Codingon the devel- } \\
\text { opment of the past tense time morpheme "ed" in two } \\
\text { school-aged children with language difficulties. } \\
\text { To observe if the benefits achieved in therapy are general- } \\
\text { ized to spontaneous speech. }\end{array}$ & English & $\begin{array}{l}1 \text { child with SLI and one child with ASD. One } \\
\text { aged } 9 \text { years old and the other } 8 \text { years old. }\end{array}$ & \\
\hline \multirow[t]{5}{*}{$\begin{array}{l}\text { Hoover J, et al. } \\
2013^{31}\end{array}$} & $\begin{array}{l}\text { To compare treatment gain and generalization in two } \\
\text { groups of children with SLI who participated in a gram- } \\
\text { matical intervention that differs in verb density. }\end{array}$ & English & $\begin{array}{l}6 \text { children between } 4.0 \text { y } 5.9 \text { years old with } \\
\text { SLI. }\end{array}$ & \\
\hline & & & Experimental group 1: & \\
\hline & & & $\begin{array}{l}3 \text { children who received intervention on third } \\
\text { person of the singular with rare verbs. }\end{array}$ & \\
\hline & & & Experimental group 2: & \\
\hline & & & $\begin{array}{l}3 \text { children who received intervention on third } \\
\text { person of the singular with dense verbs. }\end{array}$ & \\
\hline
\end{tabular}




\begin{tabular}{|c|c|c|c|c|}
\hline Article & \multirow{2}{*}{ Objective /hypothesis } & \multicolumn{3}{|c|}{ Participants } \\
\hline Author/Year & & Language & Experimental Group & Control Group \\
\hline $\begin{array}{c}\text { Washington } \mathrm{K} \text {, } \\
2013^{32}\end{array}$ & $\begin{array}{l}\text { To determine whether expressive grammar intervention } \\
\text { enables social and emerging alphabetization. } \\
\text { To determine whether the gains in expressive grammar } \\
\text { and / or initial expressive grammar level predict the re- } \\
\text { sults in social and emerging alphabetization. }\end{array}$ & English & $\begin{array}{l}\text { Experimental group 1: } \\
11 \text { children with SLI who received interven- } \\
\text { tion through a computer. } \\
\text { Experimental group 2: } \\
11 \text { children with SLI who were trained in a } \\
\text { conventional, clinician-client modality. }\end{array}$ & $\begin{array}{l}12 \text { children with SLI } \\
\text { between } 3 \text { and } 5 \text { years } \\
\text { old who did not receive } \\
\text { treatment. }\end{array}$ \\
\hline $\begin{array}{l}\text { Washington K, } \\
\text { et al. } 2013^{33}\end{array}$ & $\begin{array}{l}\text { To determine if the intervention in expressive grammar } \\
\text { (both by computer and table top intervention) generates } \\
\text { an accelerated growth of grammatical development and } \\
\text { decrease of errors in grammatical categories compared } \\
\text { to a group of children who do not receive intervention. }\end{array}$ & English & $\begin{array}{l}\text { Experimental group } 1 \text { (Computer-assisted): } \\
11 \text { children with SLI between } 3.11 \text { and } 4.6 \\
\text { years old. } \\
\text { Experimental group 2: (Table-top) } \\
11 \text { children with SLI between } 4.2 \text { and } 4.10 \\
\text { years old. }\end{array}$ & $\begin{array}{c}12 \text { children with TEL } \\
\text { between } 3.6 \text { and } 4.10 \\
\text { years old. }\end{array}$ \\
\hline
\end{tabular}

$\begin{array}{cl}\begin{array}{c}\text { Washington K, } \\ \text { et al. } 2013^{34}\end{array} & \begin{array}{l}\text { To investigate possible differences of interventions that } \\ \text { provided diverse types of } \\ \text { visual support, on the results in expressive grammar. }\end{array}\end{array}$

English

Expe 11

Experimental group 1:

11 preschoolers between 3.11 and 4.10 years old stimulated with the program CAI Computer-assisted intervention).

Experimental group 2:

11 preschoolers between 3.11 and 4.10 years old stimulated with the program TTI (Table-top intervention).

\begin{abstract}
Smith-Lock K, To compare the effectivity of a treatment aimed at expreset al. $2013^{35}$ sive grammar in children with SLI aged 5 years old, in different frequencies: 8 daily sessions or 8 weekly sessions.
\end{abstract}

Smith-Lock KM, To assess the effectivity of a school intervention program et al. $2013^{36}$ for expressive grammar in children with SLI aged 5 years old.

\section{English Experimental group 1: \\ 18 children aged 5 years old with SLI with daily therapy.}

Experimental group 2:

13 children aged 5 years old with SLI who received weekly therapy.

English 19 children aged 5 years old with SLI with $\quad 15$ children aged 5 treatment for expressive grammar. years old with control therapy: regular program from the school, centered in preposition comprehension.

\footnotetext{
Smith-Lock KM To compare the effectivity of two planned modalities et al. 2015 of feedback: "recasting approach" versus "cueing approach"
}

\author{
English Experimental group 1: \\ 14 children aged 5 years old with SLI who \\ received "cueing approach"
}

Experimental group 2:

17 children aged 5 years old with SLI who received "recasting approach"

\begin{tabular}{ll}
\hline $\begin{array}{c}\text { Plante E, et al. } \\
2014^{38}\end{array}$ & $\begin{array}{l}\text { To compare two treatments: high variability and low vari- } \\
\text { ability on the learning of grammar in children with SLI. } \\
\text { Hypothesis: }\end{array}$ \\
1. The gains for stimulated morphological forms will be \\
greater than for non-intervened morphemes in any of the \\
two treatments. \\
2. The use of 24 unique verbal sources (high variability \\
condition) would produce greater treatment effects than \\
the use of 12 unique verbal sources.
\end{tabular}

\section{English Experimental group 1:}

9 children with SLI between 4.0 and 5.11 years old on a 'low variability' therapy which implies intervention based on the use of 12 verbs.

Experimental group 2:

9 children with SLI between

4.0 and 5.11 years old on a 'high variability' treatment which implies the use of 24 verbs. 


\begin{tabular}{|c|c|c|c|c|}
\hline Article & \multirow{2}{*}{ Objective /hypothesis } & \multicolumn{3}{|c|}{ Participants } \\
\hline Author/Year & & Language & Experimental Group & Control Group \\
\hline $\begin{array}{l}\text { Hsu HJ, et al. } \\
2014^{39}\end{array}$ & $\begin{array}{l}\text { To know whether comprehension of short reversible } \\
\text { sentences can be improved through computer-based } \\
\text { training. } \\
\text { To know if the learning process in children with SLI is } \\
\text { similar to the one in younger children with typical devel- } \\
\text { opment. }\end{array}$ & English & $\begin{array}{l}28 \text { children with SLI between } 6 \text { and } 11 \text { years } \\
\text { old. }\end{array}$ & $\begin{array}{c}\text { Control group } 1 \text { : } \\
28 \text { children with typical } \\
\text { development aged } 4 \text { to } 7 \\
\text { years old who were paired } \\
\text { with the group with SLI } \\
\text { on gross results for the } \\
\text { receptive grammar test. }\end{array}$ \\
\hline
\end{tabular}

Control group 2:

20 children with SLI, with

the same tests but without therapy.

\begin{tabular}{|c|c|}
\hline $\begin{array}{l}\text { Zwitserlood R, } \\
\text { et al. } 2015^{40}\end{array}$ & $\begin{array}{l}\text { To examine the effectivity of a combined metalinguistic } \\
\text { and multimodal approach on a more advances school } \\
\text { age in children with SLI. }\end{array}$ \\
\hline \multirow[t]{3}{*}{$\begin{array}{l}\text { Meyers- } \\
\text { Denman Ch., et } \\
\text { al. } 2016^{41}\end{array}$} & $\begin{array}{l}\text { Hypothesis 1: Intervention of an objective morpheme } \\
\text { generates a statistically significant improvement (inde- } \\
\text { pendent of which of the treatments is applied). Said gain } \\
\text { is not to be observed on non-intervened morphemes } \\
\text { (control morphemes). }\end{array}$ \\
\hline & $\begin{array}{l}\text { Hypothesis 2: There may be a difference according to the } \\
\text { treatment dosage between both groups. }\end{array}$ \\
\hline & $\begin{array}{l}\text { Hypothesis } 3 \text { : The results obtained may vary on a longer } \\
\text { term. }\end{array}$ \\
\hline $\begin{array}{l}\text { Calder S, et al. } \\
\qquad 2017^{42}\end{array}$ & $\begin{array}{l}\text { To investigate the efficacy of combined explicit and } \\
\text { implicit intervention techniques, delivered by a Speech } \\
\text { therapist to improve receptive and expressive interven- } \\
\text { tion, including the use of past tense. }\end{array}$ \\
\hline $\begin{array}{l}\text { Owen, A. et al. } \\
2017^{43}\end{array}$ & $\begin{array}{l}\text { To determine whether starting the treatment with phono- } \\
\text { logically simple, frequent and telic verbs (easy verbs) or } \\
\text { with phonologically complex, infrequent and atelic verbs } \\
\text { (difficult verbs), enables a greater progress in children } \\
\text { with SLI, in their production of trained or untrained verbs. }\end{array}$ \\
\hline
\end{tabular}
with SLI, in their production of trained or untrained verbs.

\author{
Dutch 12 Dutch children with SLI with an average \\ age of 11 years old.
}

English Experimental group 1:

8 children with SLI between 4 and 5 years old, with a median of 5.4 years old, on a continued 30 minutes therapy.

Experimental group 2:

8 children with SLI between 4 and 5 years old, with a median of 5.3 years old, on a spaced treatment, 3 times 10 minutes in a 4 hour time frame.

English 3 children between 6 and 7 years old with an alteration in language development.

English 18 children with SLI.

Experimental group 1:

10 children on the treatment initiated with easy verbs. Average age: 63.1 months.

Experimental group 2:

8 children on treatment initiated with difficult verbs. Average age: 72.75 months.

Owen et al., To update the results of the Owen et al., 2007 study. Such $2018^{44} \quad$ update included three additional children in the sample.

English 20 children. Of these, 17 correspond to Owen et al., 2017.

Experimental group 1:

10 children on the treatment initiated with easy verbs. Average age 64.7 months.

Experimental group 2:

10 children on the treatment initiated with difficult verbs. Average age 70.8 months

\begin{tabular}{clll} 
Ramírez- & To study the effects of an intervention program designed \\
$\begin{array}{c}\text { Santana G, et } \\
\text { to improve grammatical abilities in students with SLI. }\end{array}$ & Spanish & $\begin{array}{l}34 \text { students diagnosed with SLI (average } \\
\text { age } 8 \text { years old). }\end{array}$ & $\begin{array}{r}34 \text { children with typical } \\
\text { language development } \\
\text { (average age } 7.9 \text { years old) }\end{array}$ \\
\hline
\end{tabular}

Legend: SLI (specific language impairment) / ASD (autistic spectrum disorder) /MLT (milieu language teaching) /BTR (broad target recasts) / CAI (Computer-assisted intervention) / TTI (Table-top intervention) 
The data in Table 3 indicate that $83 \%$ of the researches are carried out in English-speaking children. This implies a limitation because the results cannot always be extrapolated to children who speak other languages, since the grammatical difficulties in children with SLI manifest differently in each language ${ }^{10}$. This is consistent with what has been previously stated by Leonard ${ }^{21}$, regarding the fact that the greatest amount of information about grammar comprehension in children with SLI has been obtained from studies with English speakers.

Another noteworthy aspect is that $87 \%$ of the interventions focus on supporting expressive grammar. These findings agree with what Ebbels'16 proposes, which indicates that there are persistent gaps in the intervention, in particular in treatments aimed at receptive aspects. It is important to note that 3 investigations (in which the therapies were not focused on grammatical comprehension) showed that children also benefited at a comprehensive level. Thus, the work of Calder et al. ${ }^{42}$, which uses combined approaches, Zwitserlood et al ${ }^{40}$, which uses the metalinguistic approach and Camarata et al. ${ }^{26}$ that uses implicit approaches to work expressive grammar, indicated that children were favored both expressively and comprehensively. These results suggest that the approach to grammatical comprehension can be performed indirectly, in particular the explicit or metalinguistic approach seems to be useful for receptive grammatical difficulties. Ebbels ${ }^{16}$ also agrees that explicit approaches are appropriate to support students with receptive grammatical difficulties.

In addition, it can be observed that the age ranges are different in the studies. Thus, it is appreciated that $78 \%$ of the participants are preschoolers whose ages range between 2 and 6 years old. Moreover, in $26 \%$ of the studies the subjects are under 5 years old, which is controversial since before this age the diagnosis of SLI is debatable. This is because it is possible to confuse this diagnosis with a language delay. This may impact the results of the investigation, given that children with language delay generally progress faster than children with SLI when an intervention program is applied ${ }^{45}$.

Regarding the type of studies, it is observed that $83 \%$ of them compare independent samples, that is, they contrast groups that receive different types of interventions or groups with different diagnosis (SLI and TD) to which the same intervention is applied.

Table 4 shows the characteristics of the treatment and the conclusions obtained after the intervention.

The characteristics of the treatment were analyzed using the following categories: modality (individual and group), dose (number of sessions, session length and duration of treatment), approach and intervention techniques or procedures. The elements referred to the dose are relevant to specify the nature of the treatment ${ }^{16}$. Finally, it is important to note that the approach was inferred from information about the techniques or procedures of the treatment. 
Table 4. Characteristics of the treatment and conclusions of the intervention

\begin{tabular}{|c|c|c|c|c|c|}
\hline Article & & & Experimen & I group treatment & \\
\hline Author/Year & Frequency & Individual/group & Approach & Techniques/Procedures & Conciusions \\
\hline $\begin{array}{l}\text { Leonard L, } \\
\text { et al. } 2008^{23}\end{array}$ & $\begin{array}{c}4 \text { weekly } \\
\text { sessions of } 30 \\
\text { minutes each. } \\
96 \text { sessions } \\
\text { were performed } \\
\text { in } 24 \text { weeks. }\end{array}$ & $\begin{array}{l}\text { It is not specified } \\
\text { in the article but } \\
\text { it can be inferred } \\
\text { that it is individual. }\end{array}$ & Implicit & $\begin{array}{l}3 \text { programs were developed. In two of them a specific } \\
\text { agreement morpheme was stimulated in a focused manner } \\
\text { and in the third one general language was stimulated. } \\
\text { Each one of them consisted in two activities. The first one } \\
\text { consisted in telling a story using toys that performed the } \\
\text { scenes, where the structures to be stimulated were used } \\
\text { (12 times). The second one consisted in a conversation } \\
\text { where using a game, reformulations were made (12 } \\
\text { reformulations). In the group that received a general } \\
\text { stimulation of language, third person of the plural was used } \\
\text { for the story and for the conversation. }\end{array}$ & $\begin{array}{l}\text { Both group } 1 \text { and group } 2 \\
\text { improved after the intervention } \\
\text { and did not regress after one } \\
\text { month. In the group of children } \\
\text { who had global intervention the } \\
\text { results in general terms were } \\
\text { lower. It is concluded that a } \\
\text { grammatical intervention with } \\
\text { objective morphemes is better } \\
\text { than addressing grammatical } \\
\text { stimulation globally. }\end{array}$ \\
\hline
\end{tabular}

Both group 1 and 2 showed an improvement after intervention and did not regress after one month.

\begin{tabular}{|c|c|c|}
\hline $\begin{array}{l}\text { Leonard, L. } \\
\text { el al. } 2017^{24}\end{array}$ & $\begin{array}{c}96 \text { sessions: } \\
\text { two times per } \\
\text { week }\end{array}$ & individual \\
\hline
\end{tabular}

Treatment was based on implicit approaches. The session Children's language samples was divided in two parts. In the first part the clinician read indicated that the group had an a story to the child, represented with dolls. In each story increase in the use of past tense the third person singular appeared 12 times on at least 6 morphemes, auxiliaries, the different verbs. Once the reading was over, the second part third singular person and verbal started, using reformulation. Using the past tense "ed", consistency.

copulative and auxiliaries "is", "are","am", "was" and In addition, an increase in time "were" was avoided. use and concordance with limited diversity and productivity was observed in the initial measures. In the latest measures it is observed that increase in diversity and productivity occurs with little change in accuracy.

\begin{tabular}{|c|c|c|c|c|c|}
\hline $\begin{array}{l}\text { Motsch H, et } \\
\text { al. } 2008^{25}\end{array}$ & $\begin{array}{l}12 \text { hours of } \\
\text { therapy. } \\
\text { The sessions } \\
\text { lasted } 17 \\
\text { minutes, } 4 \\
\text { times per week, } \\
\text { for } 12 \text { weeks. }\end{array}$ & $\begin{array}{l}\text { Common } \\
\text { classroom most } \\
\text { of the time. The } \\
\text { support was } \\
\text { given in a group } \\
\text { or individual } \\
\text { setting, on some } \\
\text { occasions. }\end{array}$ & Implicit & $\begin{array}{l}\text { Context-Optimization (CO) intervention strategy. It is a } \\
\text { method of grammatical facilitation that optimizes naturally } \\
\text { presented contexts. Children are required to focus on the } \\
\text { objective structure. The processing and structure chosen } \\
\text { is made explicit. In this method the professional adapts } \\
\text { the articulation, facilitating the perception with extensions, } \\
\text { intonations, etc. There is a varied use of resources to } \\
\text { support children. } \\
\text { In the control group modeling approaches were used to } \\
\text { support students, for example, corrective feedback. }\end{array}$ & $\begin{array}{l}\text { Classroom CO therapy is effective } \\
\text { for both accusative and dative, } \\
\text { while traditional methods are only } \\
\text { effective for accusatives. } \\
\text { The group to which CO was applied } \\
\text { achieved better performance than } \\
\text { the control group, to which a } \\
\text { traditional method was applied. }\end{array}$ \\
\hline $\begin{array}{l}\text { Camarata S, } \\
\text { et al. } 2009^{26}\end{array}$ & $\begin{array}{l}24 \text { sessions for } \\
12 \text { weeks. } \\
\text { Two times per } \\
\text { week, for one } \\
\text { hour. }\end{array}$ & $\begin{array}{l}\text { Individual therapy } \\
\text { at a treatment } \\
\text { center. }\end{array}$ & Implicit & $\begin{array}{l}\text { The intervention techniques used were imitation, modeling, } \\
\text { conversational reformulation and Milleu Teaching (teaching } \\
\text { of the middle). The description of this method is found in } \\
\text { the article by Yoder et al, } 2011 \text {. }\end{array}$ & $\begin{array}{l}\text { The group of children who had } \\
\text { expressive language intervention } \\
\text { showed a significant increase in } \\
\text { receptive language scores. These } \\
\text { gains were significantly greater } \\
\text { than those observed in the control } \\
\text { group. }\end{array}$ \\
\hline
\end{tabular}




\begin{tabular}{|c|c|c|c|c|c|}
\hline Article & & & Experimer & group treatment & Conclucione \\
\hline Author/Year & Frequency & Individual/group & Approach & Techniques/Procedures & Contiustonis \\
\hline $\begin{array}{l}\text { Yoder P, et } \\
\text { al. } 2011^{27}\end{array}$ & $\begin{array}{l}30 \text { minutes } \\
\text { sessions, three } \\
\text { sessions per } \\
\text { week, for } 6 \\
\text { months. }\end{array}$ & $\begin{array}{l}\text { At a university } \\
\text { clinic, individual } \\
\text { sessions. }\end{array}$ & Implicit & $\begin{array}{l}\text { Two methods of grammatical intervention were used: } \\
\text { Milieu language teaching (MLT): a system of gradual and } \\
\text { environmental aids is used to generate specific linguistic } \\
\text { structures and functional or verbal rewards. The context was } \\
\text { directed game. For example, if a child at the one-wordstage } \\
\text { says "ball" while stretching to take a ball, the adult may hold } \\
\text { the ball while looking expectantly at the child. If the child } \\
\text { does not respond, the adult may ask: "What do you want?" } \\
\text { If the child still does not respond while looking at the ball the } \\
\text { adult can say: "Say,, I want the ball"”, provoking an imitation } \\
\text { request. If the child says: "I want ball," the adult could say, } \\
\text { "You want the ball" and give the child the ball. An aid is } \\
\text { provided only to obtain the desired response, and once this } \\
\text { aid is obtained it disappears. } \\
\text { Broad target recasts (BTR): This intervention is based } \\
\text { on the child's play, talk revolves around what the child is } \\
\text { paying attention to, the child is asked about what they are } \\
\text { doing and recast is doneconcerning what the child said. } \\
\text { This means that much of the child says is repeated, but } \\
\text { adding grammatical and semantic content. The child is not } \\
\text { forced to produce a specific grammatical expression. } \\
\text { In short, MLT and BTR are child centered. Both userecast } \\
\text { as a result of the child's expressions. MLT uses a previously } \\
\text { selected target grammar structure level, while BTR uses } \\
\text { grammar targets selected in the moment. MLT seeks to } \\
\text { obtain an immediate production of the given model or } \\
\text { imitate the recast, which does not occur in BTR. }\end{array}$ & $\begin{array}{l}\text { MLT enablesan improvement in } \\
\text { Grammar, more than BTR in } \\
\text { children who were initially in } \\
\text { Stage I of Brown. } \\
\text { The effects are maintained } 5 \\
\text { months after the end of the } \\
\text { treatment. }\end{array}$ \\
\hline
\end{tabular}

\begin{tabular}{|c|c|c|c|c|c|}
\hline $\begin{array}{l}\text { Yoder P, et } \\
\text { al. } 2013^{28}\end{array}$ & $\begin{array}{l}30 \text { minutes } \\
\text { sessions, three } \\
\text { sessions per }\end{array}$ & $\begin{array}{l}\text { At a university } \\
\text { clinic, individual } \\
\text { sessions. }\end{array}$ & Implicit & $\begin{array}{l}\text { In the experimental group some children received therapy } \\
\text { with Milieu language teaching (MLT) and others with Broad } \\
\text { target recasts (BTR). }\end{array}$ & $\begin{array}{l}\text { Speech processing speed was } \\
\text { higher in children with typical } \\
\text { development, before treatment. }\end{array}$ \\
\hline
\end{tabular}

week, for 6

months

After 6 months of treatment, children with SLI increase their speech processing speed. This processing speed did not show differences between both types of treatment.

The change in Speech processing speed is positively related to the improvement rate of grammar during treatment in the group of children with SLI.

\begin{tabular}{cccc}
\hline Gallego JL. & 1 weekly & In small groups & Implicit \\
$2012^{29}$ & session of 30 & and on some \\
& minutes. The & occasions, there & \\
number of & was individual & \\
weeks is not & intervention with & \\
informed. & children who \\
presented a slower & learning rhythm \\
& & and progress.
\end{tabular}

Program for the Development of Morphosyntax (P0. There are significant differences DE.MOS). This is an open program that is structured between the groups,fact thatis around five series with which different basic grammatical attributed to the PO.DE.MOS structures are stimulated. The difficulty of the activities is program. progressive.

It is pointed out that it is not a grammar program, but an It is indicated that this program expression program, formulated in grammatical terms. was useful for increasing When the child made a mistake in one of the stimulated morphosyntactic skills in the structures, direct correction was avoided, since first there children who were intervened. was an attempt to help them notice the error through questions. If this did not happen, the error was corrected and explanations were delivered.

Care was taken to positively reinforce children's achievements. 


\begin{tabular}{|c|c|c|c|c|c|}
\hline \multirow{2}{*}{$\begin{array}{c}\text { Article } \\
\text { Author/Year }\end{array}$} & \multicolumn{4}{|c|}{ Experimental group treatment } & \multirow{2}{*}{ Conclusions } \\
\hline & Frequency & Individual/group & Approach & Techniques/Procedures & \\
\hline $\begin{array}{l}\text { Kulkarni A, } \\
\text { et al. } 2013^{30}\end{array}$ & $\begin{array}{l}\text { Once a week } \\
\text { for } 10 \text { weeks, } \\
\text { sessions of } 30 \\
\text { minutes. An } \\
\text { assistant was } \\
\text { present during } \\
\text { the sessions, } \\
\text { who repeated it } \\
\text { during the week, } \\
\text { but at home. } \\
\text { The therapy was } \\
\text { suspended for } \\
6 \text { weeks. Then, } \\
\text { it was resumed } \\
\text { for } 5 \text { more } \\
\text { sessions. }\end{array}$ & $\begin{array}{l}\text { The first } 10 \\
\text { sessions were } \\
\text { individual. } \\
\text { Of the last } 5 \\
\text { sessions, } 4 \\
\text { were in the } \\
\text { classroom with a } \\
\text { communication } \\
\text { partner and } 1 \text { of } \\
\text { them at home with } \\
\text { the parents. } \\
\text { There was also a } \\
\text { meeting only with } \\
\text { parents. }\end{array}$ & Explicit & $\begin{array}{l}\text { The individual sessions progressed as follows: } 1 \text {. } \\
\text { Introduction to Shape Coding } 2 \text {. Word identification } 3 \text {. } \\
\text { Clarification of the present versus the past } 4 \text {. Introduction } \\
\text { of the arrows to mark forms } 5 \text {. Completion of sentences } \\
\text { and correction of written and spoken errors } 6 \text {. Production } \\
\text { of written and spoken sentences. }\end{array}$ & $\begin{array}{l}\text { One of the participants improved } \\
\text { significantly in the completion of } \\
\text { sentences, which was used to } \\
\text { measure the progress through the } \\
\text { sessions, but the generalization } \\
\text { was only achieved after specific } \\
\text { activities aimed at generalization. } \\
\text { The other child made more modest } \\
\text { progress in completing sentences } \\
\text { and seemed to generalize without } \\
\text { resorting to directed activities. }\end{array}$ \\
\hline $\begin{array}{l}\text { Hoover J, et } \\
\text { al. } 2013^{31}\end{array}$ & $\begin{array}{l}2 \text { sessions of } \\
30 \text { minutes } \\
\text { every week, for } \\
6 \text { weeks. Each } \\
\text { child received } \\
12 \text { sessions. }\end{array}$ & $\begin{array}{l}\text { It is not specified } \\
\text { in the article but } \\
\text { it can be inferred } \\
\text { that it is individual. }\end{array}$ & Implicit & $\begin{array}{l}\text { Therapy began with a short story which was supported } \\
\text { with pictures of the verbs to work ( } 6 \text { verbal presentations } \\
\text { per story). Then the examiner obtained productions by verb, } \\
\text { by means of a combination between direct repetition and } \\
\text { spontaneous production. When a child omitted the target } \\
\text { structure, the examiner rephrased the sentence. Each } \\
\text { child received } 72 \text { exposures to the structure ( } 36 \text { through } \\
\text { auditory exposure and } 36 \text { through child production and } \\
\text { reformulation). The treatments only differed in the verbs } \\
\text { used. }\end{array}$ & $\begin{array}{l}\text { The gains in treatment and } \\
\text { generalization were greater for } \\
\text { children with the treatment of rare } \\
\text { verbs. }\end{array}$ \\
\hline $\begin{array}{l}\text { Washington } \\
\mathrm{K}, 2013^{32}\end{array}$ & $\begin{array}{l}10 \text { interventions } \\
\text { of } 20 \text { minutes, } \\
\text { once a week. }\end{array}$ & $\begin{array}{l}11 \text { children } \\
\text { through a } \\
\text { computer. } \\
11 \text { children on } \\
\text { clinician-client } \\
\text { therapy. }\end{array}$ & Explicit & $\begin{array}{l}11 \text { participants received computer-assisted treatment. A } \\
\text { software was used called My Sentence Builder (Washington } \\
\text { and Warr-Leeper, 2006). This program presents the } \\
\text { necessary elements to create a present progressive } \\
\text { sentence. In addition, each element of the sentence has a } \\
\text { visual representation. Children are supported and guided by } \\
\text { the speech therapist. }\end{array}$ & $\begin{array}{l}\text { Both groups of participants who } \\
\text { received grammatical intervention } \\
\text { were positively affected in social } \\
\text { skills and print concept. This did } \\
\text { not happen in the control group. } \\
\text { These gains were maintained } 3 \\
\text { months after the intervention. }\end{array}$ \\
\hline
\end{tabular}

The other 11 participants had a conventional treatment. Visual support was given through pages of books, objects, and illustrated cards with actions to facilitate grammatical productions in a game format. To facilitate the understanding of the elements of the sentence, prosodic emphasis was placed on each of them.

The social skills and knowledge of letters, words and books (print concept) were addressed in the same session in which the grammar content was worked on in both groups.

\begin{tabular}{|c|c|c|c|c|c|}
\hline $\begin{array}{l}\text { Washington } \\
\text { K, et al. } \\
2013^{33}\end{array}$ & $\begin{array}{c}20 \text { minutes } \\
\text { sessions, once } \\
\text { a week for } 10 \\
\text { weeks. }\end{array}$ & $\begin{array}{l}11 \text { children } \\
\text { through a } \\
\text { computer. } \\
11 \text { children on } \\
\text { clinician-client } \\
\text { therapy. }\end{array}$ & $\begin{array}{c}\text { Explicit } \\
\text { (computer) and } \\
\text { Implicit (Board } \\
\text { game) }\end{array}$ & $\begin{array}{l}\text { One group was assisted by computer (My Sentence } \\
\text { Builder) which has visual aids to represent semantic and } \\
\text { syntactic elements of the sentence. Besides this there was } \\
\text { modeling and repetition. For another group there was table- } \\
\text { top intervention. In this group the therapist made verbal } \\
\text { and non-visual emphasis on grammar and there were } \\
\text { specificaids only for the semantic elements of the sentence. }\end{array}$ & $\begin{array}{l}\text { Both intervened groups } \\
\text { obtained better results than the } \\
\text { non-intervened group. These } \\
\text { differences were maintained over } \\
\text { time. The two interventions did } \\
\text { not differ statistically. }\end{array}$ \\
\hline $\begin{array}{l}\text { Washington } \\
\text { K, et al. } \\
2013^{34}\end{array}$ & $\begin{array}{c}20 \text { minutes } \\
\text { sessions, once } \\
\text { a week, for } 10 \\
\text { weeks. }\end{array}$ & $\begin{array}{l}11 \text { children } \\
\text { through a } \\
\text { computer. } \\
11 \text { children on } \\
\text { clinician-client } \\
\text { therapy. }\end{array}$ & $\begin{array}{l}\text { Explicit (CAI) } \\
\text { and Implicit } \\
\text { (TTI) }\end{array}$ & $\begin{array}{l}\text { Two methods were used: Computer Assisted Intervention } \\
\text { (CAI) and (TTI). The difference was that the first one } \\
\text { incorporated visual support for both semantic and } \\
\text { grammatical sentences while TTI included only visual } \\
\text { support for semantic elements and emphasis on } \\
\text { grammatical elements. The fundamental difference between } \\
\text { the interventions were the types of visual support: In the } \\
\text { CAI, the My sentence builder program was used (each } \\
\text { syntactic element had a figure or color). The TTI used } \\
\text { images and toys. In both programs, in addition to the visual, } \\
\text { modeling, repetition, a significant context and a game } \\
\text { format were used. }\end{array}$ & $\begin{array}{l}\text { The group that used CAI } \\
\text { outperformed the TAl group in } \\
\text { efficiency and syntactic growth. } \\
\text { This study showed that the use of } \\
\text { multiple visual aids in expressive } \\
\text { grammar training enabled a } \\
\text { therapeutic advantage in grammar } \\
\text { learning from session to session } \\
\text { for preschoolers with SLI. }\end{array}$ \\
\hline
\end{tabular}




\begin{tabular}{|c|c|c|c|c|}
\hline Article & & & Experimental & group treatment \\
\hline Author/Year & Frequency & Individual/group & Approach & Techniques/Procedures \\
\hline $\begin{array}{c}\text { Smith-Lock } \\
\text { K, et al. } \\
2013^{35}\end{array}$ & $\begin{array}{c}\text { For both } \\
\text { experimental } \\
\text { groups therapy } \\
\text { lasted } 1 \text { hour. } 8 \\
\text { sessions were } \\
\text { performed. } \\
\text { Group } 1 \text { had } \\
\text { daily sessions } \\
\text { and group } \\
2 \text { weekly } \\
\text { sessions. } \\
\end{array}$ & $\begin{array}{l}\text { A first instruction } \\
\text { directed at the } \\
\text { whole classroom. } \\
\text { Then small groups } \\
\text { within the common } \\
\text { classroom (3 to } 5 \\
\text { children, according } \\
\text { to performance). }\end{array}$ & Implicit & $\begin{array}{l}\text { The speech therapist conducted a group lesson with one } \\
\text { objective and then each group performed } 3 \text { activities for } \\
\text { their specific objective. } \\
\text { The sessions consisted of game-based activities. } \\
\text { Focused stimulation techniques: modeling, imitation, direct } \\
\text { teaching and reformulation. }\end{array}$ \\
\hline $\begin{array}{c}\text { Smith-Lock } \\
\text { KM, et al. } \\
2013^{36}\end{array}$ & $\begin{array}{c}1 \text { weekly } \\
\text { session of } \\
1 \text { hour for } 8 \\
\text { weeks. }\end{array}$ & $\begin{array}{l}\text { A first instruction } \\
\text { directed at the } \\
\text { whole classroom. } \\
\text { Then small groups } \\
\text { within the common } \\
\text { classroom ( } 3 \text { to } 5 \\
\text { children, according } \\
\text { to performance). }\end{array}$ & Implicit & $\begin{array}{l}\text { The speech therapist conducted a group lesson with one } \\
\text { objective and then each group performed } 3 \text { activities for } \\
\text { their specific objective. } \\
\text { The sessions consisted of game-based activities. } \\
\text { Focused stimulation techniques: modeling, imitation, direct } \\
\text { teaching and reformulation. }\end{array}$ \\
\hline $\begin{array}{c}\text { Smith-Lock } \\
\text { KM et al. } \\
2015^{37}\end{array}$ & $\begin{array}{c}1 \text { weekly } \\
\text { session of } \\
1 \text { hour, for } 8 \\
\text { weeks. }\end{array}$ & $\begin{array}{l}\text { A first instruction } \\
\text { directed at the } \\
\text { whole classroom. } \\
\text { Then small groups } \\
\text { within the common } \\
\text { classroom (2 to } 5 \\
\text { children, according } \\
\text { to performance). }\end{array}$ & $\begin{array}{l}\text { Implicit } \\
\text { (recasting } \\
\text { approach) and } \\
\text { Explicit (cueing } \\
\text { approach) }\end{array}$ & $\begin{array}{l}\text { The Speech Therapist conducted a group lesson with an } \\
\text { objective. Then, each group did } 3 \text { activities for their specific } \\
\text { objective. } \\
\text { The sessions consisted of recreational activities. } \\
\text { In both groups if the child responded correctly, the teacher } \\
\text { or speech therapist directed them to provide another model } \\
\text { of the goal and some phrase like «very good.» } \\
\text { Treatments differ when the child makes a mistake. In the } \\
\text { recasting approach group, after an error the correct answer } \\
\text { was delivered, but without trying to get the child to produce } \\
\text { it properly. } \\
\text { In the cueing approach group if the child was wrong, the } \\
\text { teacher or speech therapist followed a hierarchy of signals } \\
\text { designed for the child to produce the correct answer. These } \\
\text { signals progressively provided more support. }\end{array}$ \\
\hline
\end{tabular}

\begin{tabular}{|c|c|c|c|c|}
\hline $\begin{array}{l}\text { Plante E, et } \\
\text { al. } 2014^{38}\end{array}$ & $\begin{array}{c}\text { Daily } 30 \\
\text { minutes therapy } \\
\text { sessions, until } \\
\text { completing } 24 \\
\text { sessions. }\end{array}$ & Individual therapy. & Implicit & $\begin{array}{l}\text { The treatment consisted of reformulation in conversation. } \\
\text { The children were assigned one of two therapyoptions: } \\
\text { One of high variability where } 24 \text { verbs were used in which } \\
\text { reformulation was delivered in the conversation and one } \\
\text { of low variability where } 12 \text { verbs were used and each } \\
\text { reformulation given twice. }\end{array}$ \\
\hline
\end{tabular}

The sessions had different materials and the children selected them depending on their interest. Example: dialogic book, reading, board games, craft projects, costumes, flash cards, activitiesand free play. There were 3 activities per session.

Grammar performance improved after grammar treatment. The group of children who received a control intervention showed no differences after treatment.

Conclusions

The expressive grammar
intervention was most effective when the frequency of the sessions was weekly.

Grammar performance improved
after grammar treatment. The
group of children who received
a control intervention showed no
differences after treatment.

Cueing approach led to a greater treatment effect than recasting approach.

The success of the treatment was not related to the grammatical objective that was stimulated in the intervention.

The condition of high variability only produced significant changes in the use of morphemes trained in children, but not in other morphemes.

More children in the condition of high variability than in the one of low variability showed an effect ofthe treatment and on the production of expressions containing the treated morphemes.

Reformulation was defined as an issuance of the clinician which was followed by an attempt of the child that could be right or wrong. Right and the wrong were reformulated.

In both treatment conditions, clinicians created contexts in which the child should use the objective morpheme. 


\begin{tabular}{|c|c|c|c|c|c|}
\hline \multirow{2}{*}{$\begin{array}{c}\text { Article } \\
\text { Author/Year }\end{array}$} & \multicolumn{4}{|c|}{ Experimental group treatment } & \multirow{2}{*}{ Conclusions } \\
\hline & Frequency & Individual/group & Approach & Techniques/Procedures & \\
\hline $\begin{array}{l}\text { Hsu HJ, et } \\
\text { al. } 2014^{39}\end{array}$ & $\begin{array}{l}\text { One session per } \\
\text { day for a period } \\
\text { between } 4 \text { and } \\
6 \text { days. Each } \\
\text { session lasted } \\
\text { between } 5 \text { and } \\
7 \text { minutes. }\end{array}$ & $\begin{array}{l}\text { Each child with } \\
\text { a computer. } \\
\text { Individual }\end{array}$ & Explicit & $\begin{array}{l}\text { The computerized training program was based on the one } \\
\text { used by Bishop, Adams \& Rosen (2006). } \\
\text { The children moved some images either up / down or } \\
\text { before / after in relation to the sentence they heard. A format } \\
\text { similar to a game was adopted using an error-free learning } \\
\text { procedure. If the child gave a correct answer there was a } \\
\text { visible reward. If theyanswered incorrectly, the child had the } \\
\text { opportunity to try again. }\end{array}$ & $\begin{array}{l}\text { Control group } 1 \text { was eliminated } \\
\text { from the analysis because all but } \\
1 \text { child scored over } 90 \% \text { in the } \\
\text { pretreatment. } \\
\text { The children to whom the } \\
\text { program was applied, showed } \\
\text { better performance in repeated } \\
\text { sentences than in the sentences } \\
\text { presented only once. }\end{array}$ \\
\hline
\end{tabular}

Overall, children's scores improved with training, with the exception of the TROG-E test (receptive grammar) in which neither children with SLI nor their controls showed improvement in grammatical agreement.

The training used in the study was not enough to make the performance of children with SLI equal to a group of children with typical development of the same age.

\begin{tabular}{cccc}
\hline Zwitserlood & Twice a week & Individual & Explicit \\
R, et al. & for 5 weeks. & \\
$2015^{40}$ & 10 sessions in & \\
& total. 5 hours in & \\
& total. &
\end{tabular}

MetaTaal metalinguistic intervention approach. It uses This study supports the evidence images to represent coordination or subordination. The that grammar skills in older instruction was mostly verbal. Minor reading and writing school-aged children with SLI can activities were included. Conversations, photos, stories be remedied by direct intervention were used to elicit the children's production. Each therapy using a metalinguistic approach. session also had a game activity to consolidate the syntactic structures that were being stimulated.

It is noted that 5 hours of intervention in 5 weeks, with a metalinguistic training, can contribute to the improvement of the production of relative clauses in school-age children, but not in their understanding.

\begin{tabular}{|c|c|c|c|c|c|}
\hline $\begin{array}{c}\text { Meyers- } \\
\text { Denman Ch., } \\
\text { et al. } 2016^{41}\end{array}$ & $\begin{array}{c}\text { For both } \\
\text { experimental } \\
\text { groups the } \\
\text { therapy was } \\
\text { daily and lasted } \\
30 \text { minutes, for } \\
5 \text { weeks. For } \\
\text { group } 1 \text { the } 30 \\
\text { minutes were } \\
\text { continued and } \\
\text { for group } 2 \text { it } \\
\text { was divided in } 3 \\
\text { sessions of } 10 \\
\text { minutes each, } \\
\text { within } 4 \text { hours. }\end{array}$ & Individual & Implicit & $\begin{array}{l}\text { To determine the appropriate target morpheme, during the } \\
\text { first three days, } 4 \text { to } 6 \text { morphemes were tested for each } \\
\text { child. The clinicians had to cause the child to issue the } \\
\text { morpheme } 10 \text { timesin conversation, through play. Two } \\
\text { morphemes were selected, one of them would be treated } \\
\text { (objective morpheme) and the other tracked but not treated } \\
\text { (control morpheme). } \\
\text { The clinician rephrased the conversation with the child } \\
\text { focused on the morpheme to be treated, performed } 1 \text { time } \\
\text { (called simple reformulation). When performing the correct } \\
\text { reformulation, the clinician did not ask the child to say it } \\
\text { again or correct if they repeated the error. The dose was } 24 \\
\text { reformulations per day ( } 8 \text { every } 10 \text { minutes) directed to a } \\
\text { specific grammatical morpheme. } \\
\text { The clinicians were free to select the activities that seemed } \\
\text { appropriate and entertaining for the children but had to } \\
\text { perform at least three different activities per day with varied } \\
\text { material. Before the reformulation the clinician had to make } \\
\text { sure he had the child's attention. }\end{array}$ & $\begin{array}{l}\text { Treated morphemes showed more } \\
\text { improvement than untreated ones. } \\
\text { The children who received } \\
\text { therapy under the condition of } \\
30 \text { continued minutes showed } \\
\text { no difference from those who } \\
\text { received the } 30 \text { minutes in } \\
\text { interventions of } 10 \text { minutes each } \\
\text { in a period of } 4 \text { hours. } \\
\text { Regarding long-term } \\
\text { performance, children were } \\
\text { assessed between } 7 \text { and } 11 \\
\text { weeks after treatment. There were } \\
\text { no differences in the performance } \\
\text { of the target morpheme between } \\
\text { groups. }\end{array}$ \\
\hline
\end{tabular}




\begin{tabular}{|c|c|c|c|c|c|}
\hline Article & & & Experimen & I group treatment & Conolucion \\
\hline Author/Year & Frequency & Individual/group & Approach & Techniques/Procedures & Conciusions \\
\hline $\begin{array}{c}\text { Calder S, et } \\
\text { al. } 2017^{42}\end{array}$ & $\begin{array}{l}10 \text { sessions. } \\
\text { During } 5 \\
\text { weeks, two } \\
\text { times per week. } \\
45 \text { minutes }\end{array}$ & Individual & Explicit & $\begin{array}{l}\text { The treatment was based on explicit grammatical } \\
\text { intervention approaches using the Metacognitive training } \\
\text { techniques of Shape Coding (Ebbels, 2007) which was } \\
\text { combined with a hint hierarchy procedure, called Cueing } \\
\text { hierarchy. }\end{array}$ & $\begin{array}{l}\text { Two of the three } \\
\text { participantsadvanced in the } \\
\text { standardized tests for receptive } \\
\text { and expressive grammar. }\end{array}$ \\
\hline
\end{tabular}

sessions.

One participant continued to improve five weeks after treatment in expressive grammar.

The findings suggest that this approach was effective.

\begin{tabular}{|c|c|c|c|c|c|}
\hline $\begin{array}{l}\text { Owen, M. et } \\
\text { al. } 2017^{43}\end{array}$ & $\begin{array}{l}36 \text { visits } \\
\text { maximum. } \\
\text { Ranging } \\
\text { between } 12 \text { and } \\
36 \text { visits, of } \\
\text { approximately } \\
45 \text { minutes } \\
\text { each. }\end{array}$ & Individual & Implicit & $\begin{array}{l}\text { The treatment was based on implicit approaches. The visits } \\
\text { included three parts: imitation of sentences, modeling and } \\
\text { reading stories represented with toys. In a latter instance, } \\
\text { reformulation wasused. In each of these parts the focus } \\
\text { was verbal morphology. }\end{array}$ & $\begin{array}{l}\text { Children who began therapy with } \\
\text { more difficult verbs hadbetter } \\
\text { results than those who began } \\
\text { with easier verbs. Improvement is } \\
\text { observed both in verbs that were } \\
\text { trained and in verbs that were not } \\
\text { trained. }\end{array}$ \\
\hline $\begin{array}{l}\text { Owen, A. et } \\
\text { al., } 2018^{44}\end{array}$ & $\begin{array}{l}36 \text { visits } \\
\text { maximum. } \\
\text { Ranging } \\
\text { between } 13 \text { and } \\
36 \text { visits, of } \\
\text { approximately } \\
45 \text { minutes } \\
\text { each. }\end{array}$ & $\begin{array}{l}\text { It is not specified } \\
\text { in the article but } \\
\text { it can be inferred } \\
\text { that it is individual. }\end{array}$ & Implicit & $\begin{array}{l}\text { Same treatment performed in the study by } 0 \text { wen et al., } \\
2017\end{array}$ & $\begin{array}{l}\text { Children who started therapy with } \\
\text { the condition of difficult verbs } \\
\text { showed a greater improvement } \\
\text { in the use of the «ed» morpheme } \\
\text { for the past tense of regular verbs. } \\
\text { This gain was observed in both } \\
\text { language samples and structured } \\
\text { assessments. }\end{array}$ \\
\hline $\begin{array}{l}\text { Ramírez- } \\
\text { Santana G, } \\
\text { et al. } 2018^{45}\end{array}$ & $\begin{array}{c}216 \text { sessions } \\
\text { of } 40 \text { minutes } \\
\text { each, two times } \\
\text { per week. }\end{array}$ & $\begin{array}{l}\text { It is not specified } \\
\text { in the article but } \\
\text { it can be inferred } \\
\text { that it is individual. }\end{array}$ & Explicit & $\begin{array}{l}\text { The program combines fictional stories with } \\
\text { morphosyntactic activities. } \\
\text { In the first part ( } 30 \mathrm{~min}) \text {, the retelling of fictional stories } \\
\text { is sought. For this, the child is told a story with icons } \\
\text { supporting it. Then the child is asked to retell it. The next } \\
\text { step is telling the story without the help of icons. If the } \\
\text { child omits information or makes mistakes, the therapist }\end{array}$ & $\begin{array}{l}\text { The group with SLI improved } \\
\text { compared to controls, because } \\
\text { they reduced the number of } \\
\text { ungrammatical sentences, which } \\
\text { was reflected in the decrease } \\
\text { in syntactic and morphological } \\
\text { errors. }\end{array}$ \\
\hline
\end{tabular}
uses strategies such as questions or grammar activities in which reformulation is performed to model and correct. The materials that were used were: sheets, comics or cartoons that represent the story, different stories, icons that represent the basic categories of the narrative structure, cards and pictograms, stickers to generate stories, notebooks and pencils.

In a second part (10 min), the creation of stories is sought. Specific morphosyntax activities are conducted aimed at the adequate production of different syntactic structures. This part uses sheets containing graphic organizers or icons that include all the elements of the formal structure in sequential order and in separate squares. Grammar facilitation procedures such as modeling, reformulation, vertical structuring and imitation are delivered.

The most specific work of grammatical production involves a series of morphosyntactic activities aimed at facilitating the knowledge, understanding and production of different syntactic structures. Activities were used such as completing sentences, crossing out the incorrect words in sentences, sorting sentences presented in a disorganized manner, organizing and verbalizing sequences of actions using drawings, placing sentences on their respective balloons, organizing sentences with the help of cards and using graphic supports to associate a phrase with its drawing. For this, materials such as comics, exercise cards and card kits are used.

Legend: CO (Context-Optimization) / MLT (milieu language teaching) /BTR (broad target recasts) /SLI (specific language impairment) /PO.DE.MOS (Programa para el Desarrollo de la Morfosintaxis) /CAI (Computer-assisted intervention) /TTI (Table-top intervention) 
Table 4 shows that $60 \%$ of the studies are carried out individually. This suggests that there is some consensus that individual therapy is more appropriate for children with SLI than group therapy. This may be due to the fact that the persistence and severity of this disorder would require focused support for these children. This result differs from a study ${ }^{46}$ in which it was found that the individual modality shows a similar effect as group therapy. It should be noted that in the mentioned study each subject had their own therapeutic goal. Consequently, the results, rather than favoring a treatment modality, indicate the importance of the intervention being specific and directed to a particular grammatical aspect.

Regarding the frequency and duration of the sessions, it is noted that $65 \%$ of the studies perform between 1 and 2 sessions per week and their duration is variable, fluctuating between 5 minutes and 1 hour. It is noteworthy that the highest percentage was $39 \%$, which corresponds to studies that carried out therapy sessions of 30 minutes.

In relation to the length of the treatment, the data shows that the duration ranges from 1 week to 8 months. However, there is a tendency to execute treatments that last between 10 and 12 weeks. It is important to note that the Ramírez-Santana ${ }^{45}$ study implements the treatment for more than 1 year.

Despite the importance of evaluating the dose (number and duration of sessions / length of treatment), it was found that only the study by Smith-Lock et al ${ }^{35}$ analyzes some aspects of it. The purpose of this study was to determine which dose was most effective. Their results showed that weekly therapy, carried out for 8 weeks, was more effective than daily treatment. The findings of this investigation are consistent with what was raised by Kamhi ${ }^{15}$. This author mentions that a higher dose in therapy will not always lead to better results. It is suggested that progress may depend on other aspects such as the area to be supported and the level of development that the child manifests in that area.

This is also consistent with what is proposed by Proctor-Williams and Fey ${ }^{47}$ who express that therapy is effective when it provides varied and repeated learning opportunities that are distributed over a considerable period of time.

In relation to the approaches used, there is a tendency to perform the intervention with one type of approach. Thus, $60 \%$ of the studies were carried out with the implicit approach, $26 \%$ used therapies with the explicit or metalinguistic approach and $14 \%$ used both approaches. The results of the investigations showed that children in treatment, independent of the approach, show improvements in the areas that are stimulated. These findings are not in accord with the proposal by Ullman \& Pierpont ${ }^{1}$ and Ebbels ${ }^{16}$ in which the metalinguistic approach would be better for children with SLI, since this approach is based on declarative memory, which is not compromised ${ }^{1}$.

The predominance of treatments that use implicit approaches may be due to the age of the subjects who are supported with such treatments. Thus, 13 of the 14 studies in which the implicit approach is used work with participants who are under 6 years old. In contrast, of the 6 works in which the explicit approach is used, 5 were applied to children who were 6 years old or older. This relationship between age and type of approach is consistent with what is proposed by Ebbels ${ }^{16,18}$. The author indicates that implicit approaches are more suitable for younger children ${ }^{16}$ and explicit ones are more suitable for older children ${ }^{18}$.

Finally, it is important to note that the studies analyzed do not show explicit criteria to determine the contents that will be applied in therapy. In general, syntactic structures are mentioned, but their selection is not substantiated. This indicates that this aspect of therapy is not a focus of attention when assessing the treatments.

The limitations of this review are related to the age of the subjects and one of the inclusion criteria. The age range to which the search was limited restricted the analysis of interventions for older children with SLI. In this regard, it is important to review treatments in older subjects, because the linguistic aspect of grammar acquires relevance when learning the written language. The inclusion criterion which considered studies exclusively with grammatical interventions, limited the analysis of treatments where the grammatical component works in conjunction with other linguistic aspects in children with SLI.

\section{CONCLUSION}

The review of the articles shows that in 10 years of studies analyzed, research on grammatical treatments in children with SLI is scarce, since only 23 articles were found using the established criteria. In addition, most of them have been done with English-speaking children. Regarding the modality and the dose, the treatments tend to be individual, predominantly with therapies of one or two weekly sessions of 30 minutes. 
The intervention period tends not to exceed 6 months. Concerning the approach, most treatments use the implicit therapy and the results indicate that children with SLI benefit from any type of approach. In regards to the intervention of expressive or comprehensive aspects, there is a prevalence of studies in which expressive grammar is intervened. Finally, aspects related to grammatical contents are not specified. This suggests that there is a gap regarding the criteria applied to select the grammatical contents that can be used to support the morphosyntactic difficulties in children with SLI.

\section{REFERENCES}

1. Ullman M, Pierpont E. Specific language impairment is not specific to language: the procedural deficit hypothesis. Cortex. 2005;41(3):399-433.

2. Tomblin J, Records N, Buckwalter $P$, Zhang $X$, Smith E, O'Brien M. Prevalence of specific language impairment in kindergarten children. J Speech Lang Hear Res. 1997;40(6):1245-60.

3. Leonard LB. Children with specific language impairment. $\quad 1^{\circ} \mathrm{ed}$. Cambridge (MA): MIT Press; 1998.

4. Stothard S, Snowling M, Bishop D, Chipchase B, Kaplan C. Language-impaired preschoolers. J Speech Lang Hear Res. 1998;41(2):407-18.

5. Johnson C, Beitchman J, Young A, Escobar $M$, Atkinson L, Wilson B et al. Fourteen-year follow-up of children with and without speech/ language impairments. J Speech Lang Hear Res. 1999;42(3):744-60.

6. Aguado G. Apuntes acerca de la investigación sobre el TEL. Rev Logop Foniatr Audiol. 2007;27(3):103-9.

7. Leonard L. Specific language impairment across languages. In: Bishop B, Leonard L (orgs). In speech and language impairments in children. New York: Psychology Press;2014. p.115-30.

8. De Anda S, Blossom M, Abel A. A complexity approach to treatment of tense and agreement deficits: a case study. Commun Disord Q. 2019:1-11.

9. Rice M, Hoffman L, Wexler K. Judgments of omitted $\mathrm{BE}$ and $\mathrm{DO}$ in questions as extended finiteness clinical markers of Specific Language Impairment (SLI) to 15 years: a study of growth and asymptote. J Speech Lang Hear Res. 2009;52(6):1417-33.
10. Leonard L. Some reflections on the study of children with specific language impairment. Child Lang Teach Ther. 2009;25(2):169-71.

11. Norbury C, Bishop D, Briscoe J. Production of english finite verb morphology. J Speech Lang Hear Res. 2001;44(1):165-78.

12. Anderson R, Souto $S$. The use of articles by monolingual Puerto Rican Spanish-speaking children with specific language impairment. Appl Psycholinguist. 2005;26(04):621-47.

13. Bedore L, Leonard L. Verb inflections and noun phrase morphology in the spontaneous speech of Spanish-speaking children with specific language impairment. Appl Psycholinguist. 2005;26(02):195-225.

14. Morgan G, Restrepo M, Auza A. Comparison of Spanish morphology in monolingual and SpanishEnglish bilingual children with and without language impairment. Biling Lang Cogn. 2013;16(03):578-96.

15. Kamhi A. Improving clinical practices for children with language and learning disorders. Lang Speech Hear Ser. 2014;45(2):92-103.

16. Ebbels $\mathrm{S}$. Effectiveness of intervention for grammar in school-aged children with primary language impairments: a review of the evidence. Child Lang Teach Ther. 2014;30(1):7-40.

17. Cleave $P$, Becker S, Curran M, Owen A, Fey M. The efficacy of recasts in language intervention: $A$ systematic review and meta-analysis. Am J Speech Lang Pathol. 2015;24(2):237-55.

18. Ebbels S. Teaching grammar to school-aged children with specific language impairment using Shape Coding. Child Lang Teach Ther. 2007;23(1):67-93.

19. Finestack L, Satterlund K. Current practice of child grammar intervention: a survey of speechlanguage pathologists. Am J Speech Lang Pathol. 2018;27(4):1329-51.

20. Plante E, Mettler H, Tucci A, Vance R. Maximizing treatment efficiency in developmental language disorder: positive effects in half the time. Am J Speech Lang Pathol. 2019;28(3):1233-47.

21. Leonard L, Kueser J. Five overarching factors central to grammatical learning and treatment in children with developmental language disorder. Int J Lang Commun Disord. 2019;54(3):341-61.

22. Zambrana JR. La situación actual de la lengua española en el mundo. [septiembre 2009]. Disponible en http://www.eumed.net/rev/cccss/05/ jrz.htm 
23. Leonard L, Camarata S, Pawlowska M, Brown $B$, Camarata $M$. The acquisition of tense and agreement morphemes by children with specific language impairment during intervention: phase 3. J Speech Lang Hear Res. 2008;51(1):120-5.

24. Leonard L, Haebig H, Deevy P, Brown B. Tracking the growth of tense and agreement in children with specific language impairment: differences between measures of accuracy, diversity, and productivity. J Speech Lang Hear R. 2017;60:3590-600.

25. Motsch H, Riehemann S. Effects of 'ContextOptimization' on the acquisition of grammatical case in children with specific language impairment: an experimental evaluation in the classroom. Int $\mathrm{J}$ Lang Commun Disord. 2008;43(6):683-98.

26. Camarata S, Nelson K, Gillum H, Camarata M. Incidental receptive language growth associated with expressive grammar intervention in SLI. First Lang. 2009;29(1):51-63.

27. Yoder P, Molfese D, Gardner E. Initial mean length of utterance predicts the relative efficacy of two grammatical treatments in preschoolers with specific language impairment. J Speech Lang Hear Res. 2011;54(4):1170-81.

28. Yoder P, Molfese D, Murray M, Key A. Normative topographic ERP analyses of speed of speech processing and grammar before and after grammatical treatment. Dev Neuropsychol. 2013;38(8):514-33.

29. Gallego JL. La enseñanza de habilidades lingüísticas en morfosintaxis: evaluación de un programa de intervención. Investigación en la escuela. 2012;76:77-91.

30. Kulkarni A, Pring $T$, Ebbels $S$. Evaluating the effectiveness of therapy based around Shape Coding to develop the use of regular past tense morphemes in two children with language impairments. Child Lang Teach Ther. 2013;30(3):245-54.

31. Hoover J, Storkel H. Grammatical treatment and specific language impairment: Neighbourhood density \& third person singular - s. Clin Linguist Phon. 2013;27(9):661-80.

32. Washington $\mathrm{K}$. The association between expressive grammar intervention and social and emergent literacy outcomes for preschoolers with SLI. Am J Speech Lang Pathol. 2013;22(1):113-25.

33. Washington K, Warr-Leeper G. Growth in expressive grammar following intervention for 3- to 4-year-old preschoolers with SLI. JCPSLP. 2013;15(1):7-12.
34. Washington K, Warr-Leeper G. Visual support in intervention for preschoolers with specific language impairment. Top Lang Disord. 2013;33(4):347-65.

35. Smith-Lock K, Leitão S, Lambert L, Prior P, Dunn A, Cronje J et al. Daily or weekly? The role of treatment frequency in the effectiveness of grammar treatment for children with specific language impairment. Int J Speech Lang Pathol. 2013;15 (3):255-67.

36. Smith-Lock KM, Leitao S, Lambert L, Nickels L. Effective intervention for expressive grammar in children with specific language impairment. Int J Lang Commun Disord. 2013;48(3):265-82.

37. Smith-Lock KM, Leitão S, Prior P, Nickelsa L. The effectiveness of two grammar treatment procedures for children with SLI: a randomized clinical trial. Lang Speech Hear Ser. 2015;46(4):312-24.

38. Plante E, Ogilvie T, Vance R, Aguilar J, Dailey N, Meyers $\mathrm{C}$ et al. Variability in the language input to children enhances learning in a treatment context. Am J Speech Lang Pathol. 2014;23(4):530-46.

39. Hsu HJ, Bishop D. Training understanding of reversible sentences: a study comparing languageimpaired children with age-matched and grammarmatched controls. Peer J. 2014;2:e656.

40. Zwitserlood R, Wijnen F, van Weerdenburg $M$, Verhoeven L. 'MetaTaal': enhancing complex syntax in children with specific language impairment-a metalinguistic and multimodal approach. Int J Lang Commun Disor. 2015;50(3):273-97.

41. Meyers-Denman Ch, Plante E. Dose schedule and enhanced conversational recast treatment for children with specific language impairment. Lang Speech Hear Ser. 2016;47:334-46.

42. Calder S, Claessen M, Leitão S. Combining implicit and explicit intervention approaches to target grammar in young children with developmental language disorder. Child Lang Teach Ther. 2017;34(2):171-89.

43. Owen A, Fey M, Curran M. Do the hard things first: a randomized controlled trial testing the effects of exemplar selection on generalization following therapy for grammatical morphology. J Speech Lang Hear R. 2017;60(9):2569-88.

44. Owen A, Curran M, Larson C, Fey M. Effects of a complexity-based approach on generalization of past tense -ed and related morphemes. Lang Speech Hear Ser. 2018;49:681-93.

45. Ramírez-Santana G, Acosta-Rodríguez V, MorenoSantana A, del Valle-Hernández N, Axpe-Caballero Á. El uso combinado de narraciones orales 
y actividades morfosintácticas para mejorar habilidades gramaticales de alumnado con trastorno específico del lenguaje (TEL). Revista de Psicodidáctica. 2018;23(1):48-55.

46. Eidsvåg S, Plante $\mathrm{E}$, Oglivie $\mathrm{T}$, Privette $\mathrm{CH}$, Mailend $M$. Individual versus small group treatment of morphological errors for children with developmental language disorder. Lang Speech Hear Ser. 2019;50:237-52.

47. Proctor-Williams K, Fey M. Recast density and acquisition of novel irregular past tense verbs. J Speech Lang Hear Res. 2007;50(4):1029-47. 